\title{
Nitrous oxide in the North Atlantic Ocean
}

\author{
S. Walter ${ }^{1, *}$, H. W. Bange ${ }^{1}$, U. Breitenbach ${ }^{1}$, and D. W. R. Wallace ${ }^{1}$ \\ ${ }^{1}$ Forschungsbereich Marine Biogeochemie, IFM-GEOMAR, Leibniz-Institut für Meereswissenschaften, Kiel, Germany \\ *now at: Institute for Marine and Atmospheric Research Utrecht, Utrecht University, Utrecht, The Netherlands
}

Received: 2 May 2006 - Published in Biogeosciences Discuss.: 17 July 2006

Revised: 10 November 2006 - Accepted: 21 November 2006 - Published: 1 December 2006

\begin{abstract}
In order to get a comprehensive picture of the distribution of nitrous oxide $\left(\mathrm{N}_{2} \mathrm{O}\right)$ in the North Atlantic Ocean, measurements of dissolved nitrous oxide were made during three cruises in the tropical, subtropical and coldtemperate North Atlantic Ocean in October/November 2002, March/April 2004, and May 2002, respectively. To account for the history of atmospheric $\mathrm{N}_{2} \mathrm{O}$, we suggest a new depthdependent calculation of excess $\mathrm{N}_{2} \mathrm{O}\left(\Delta \mathrm{N}_{2} \mathrm{O}\right) . \mathrm{N}_{2} \mathrm{O}$ depth profiles showed supersaturation throughout the water column with a distinct increasing trend from the cold-temperate to the tropical region. Lowest nitrous oxide concentrations, near equilibrium and with an average of $11.0 \pm 1.7 \mathrm{nmol} \mathrm{L}^{-1}$, were found in the cold-temperate North Atlantic where the profiles showed no clear maxima. Highest values up to $37.3 \mathrm{nmol} \mathrm{L}-1$ occurred in the tropical North Atlantic with clear maxima at approximately $400 \mathrm{~m}$. A positive correlation of nitrous oxide with nitrate, as well as excess nitrous oxide with the apparent oxygen utilization (AOU), was only observed in the subtropical and tropical regions. Therefore, we conclude that the formation of nitrous oxide via nitrification occurs in the tropical region rather than in the cold-temperate region of the North Atlantic Ocean
\end{abstract}

\section{Introduction}

Nitrous oxide $\left(\mathrm{N}_{2} \mathrm{O}\right)$ is an important atmospheric trace gas due to its influence on the Earth's climate. In the troposphere $\mathrm{N}_{2} \mathrm{O}$ acts as a greenhouse gas whereas in the stratosphere it is involved in the depletion of ozone by providing NO-radicals (Prather et al., 2001). Since the beginning of the industrial revolution the global mean tropospheric $\mathrm{N}_{2} \mathrm{O}$ mole fraction has risen rapidly from $270 \mathrm{ppb}$ up to $314 \mathrm{ppb}$ in 1998 (Prather et al., 2001). About 24\% of the natural

Correspondence to: S. Walter

(s.walter@phys.uu.nl) sources of atmospheric $\mathrm{N}_{2} \mathrm{O}$ are contributed by the oceans (Prather et al., 2001; Seitzinger et al., 2000). Nitrous oxide is an important component of the oceanic nitrogen cycle, mainly formed by the microbial processes of nitrification and denitrification (Codispoti et al., 2001; Goreau et al., 1980): Nitrification is an aerobic two-step process in which ammonium is oxidized to nitrate $\left(\mathrm{NH}_{4}^{+} \rightarrow \mathrm{NH}_{2} \mathrm{OH} \rightarrow \mathrm{NO}_{2}^{-} \rightarrow \mathrm{NO}_{3}^{-}\right)$ by two different groups of microbes. In this process nitrous oxide is assumed to be a by-product, however the exact pathway for $\mathrm{N}_{2} \mathrm{O}$ production remains unclear. In suboxic habitats nitrate can be reduced by denitrification to molecular nitrogen $\left(\mathrm{NO}_{3}^{-} \rightarrow \mathrm{NO}_{2}^{-} \rightarrow \mathrm{NO} \rightarrow \mathrm{N}_{2} \mathrm{O} \rightarrow \mathrm{N}_{2}\right)$, here nitrous oxide is an intermediate product. Especially at oxic/suboxic boundaries $\mathrm{N}_{2} \mathrm{O}$ is produced by coupled nitrification and denitrification, due to the transfer of common intermediates (Yoshinari et al., 1997). Another possibility is aerobic denitrification, whereby under fully aerobic conditions organisms convert ammonia into nitrogen gas without the intermediary accumulation of nitrite (Robertson et al., 1988). All processes depend on oxygen concentrations, as well as the availability of substrates such as ammonium and nitrate. Many organisms are able to switch between different pathways depending on environmental conditions, and also the yield of $\mathrm{N}_{2} \mathrm{O}$ during a process depends on environmental conditions (Goreau et al., 1980; Poth and Focht, 1985; Richardson, 2000). Positive correlations of $\mathrm{N}_{2} \mathrm{O}$ with apparent oxygen utilization (AOU) or nitrate are interpreted as production of nitrous oxide by nitrification (Yoshinari, 1976; Cohen and Gordon, 1978; Yoshida et al., 1989). However, the dominant production pathway for $\mathrm{N}_{2} \mathrm{O}$ on the global scale and the contribution of different pathways still remains unclear (Codispoti et al., 2001; Popp et al., 2002). Information on the vertical $\mathrm{N}_{2} \mathrm{O}$ distribution in the North Atlantic is sparse, only a few profiles are available. The first vertical profiles for the North Atlantic were published by Junge and Hahn (1971) and Yoshinari (1976), additional data were collected by Butler et al. (1995), and recently data from a transect at

Published by Copernicus GmbH on behalf of the European Geosciences Union. 


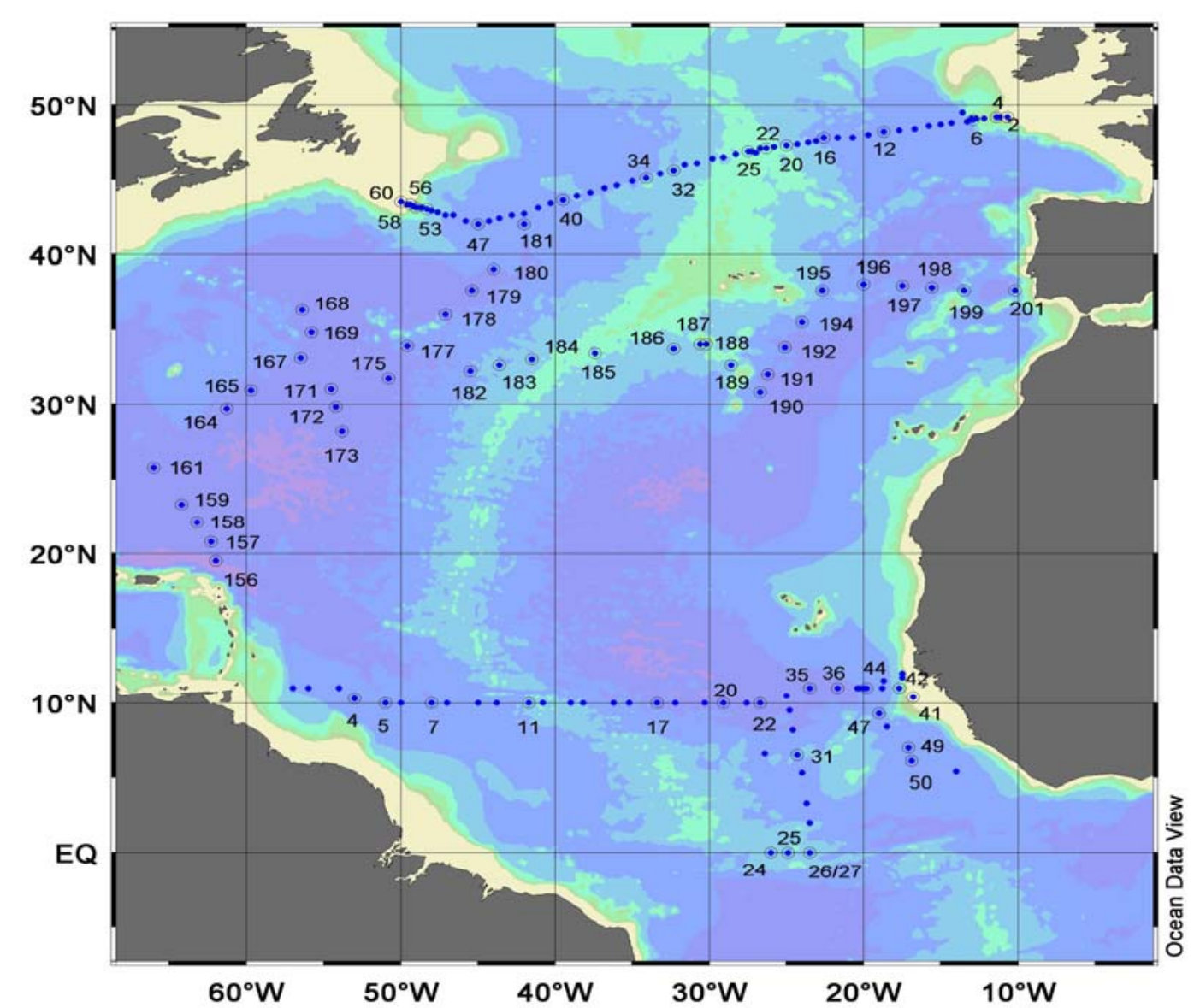

Fig. 1. Cruise tracks for "Gauss 384-1" (cold-temperate North Atlantic, 16th May to 14th June 2002), "Meteor 60-5" (subtropical North Atlantic, 9th March to 14th April 2004) and "Meteor 55" (tropical North Atlantic, 13th October to 16th November 2002). Numbers are given for stations where $\mathrm{N}_{2} \mathrm{O}$ profiles were measured.

$7^{\circ} 30^{\prime} \mathrm{N}$ were reported by Oudot et al. (2002). In this paper we present a comprehensive set of 73 vertical profiles of nitrous oxide from three trans-Atlantic cruises, covering the cold-temperate North Atlantic, the subtropical and the tropical North Atlantic. Based on these new data, we examine the regional differences of the $\mathrm{N}_{2} \mathrm{O}$ distribution and its relationship with parameters closely related to the production pathways of $\mathrm{N}_{2} \mathrm{O}$.

\section{Study area}

\subsection{Research cruises}

Samples from the three cruises were collected over the period from May 2002 to April 2004 (see Fig. 1).

The first cruise, to the cold-temperate North Atlantic (May/June 2002), started in Hamburg, Germany with the German research vessel "Gauss". The cruise track followed the WOCE-A2 transect to Halifax, Canada. Depth profiles of
$\mathrm{N}_{2} \mathrm{O}$ were measured at 16 stations. The WOCE-A2 transect is located between $42^{\circ} \mathrm{N}$ and $49^{\circ} \mathrm{N}$.

The subtropical North Atlantic was investigated during March/April 2004 onboard the research vessel "Meteor". The cruise started in Fort de France, Martinique (French Antilles) in the western part of the Atlantic and ended in Lisbon (Portugal). Samples were taken at 37 stations. Most stations were co-located with stations where samples were taken during the Transient Tracers in the Ocean Program (TTO) in 1982.

The tropical North Atlantic samples were taken during the M55-SOLAS cruise (Wallace and Bange, 2004) in October/November 2002, again with the German research vessel "Meteor". This cruise started in the western tropical North Atlantic in Willemstad, Curaçao (Netherlands Antilles) and followed a cruise track along $10-11^{\circ} \mathrm{N}$ to Douala (Cameroon). The track included a transect to the equator between $26^{\circ} \mathrm{W}$ and $23.5^{\circ} \mathrm{W} . \mathrm{N}_{2} \mathrm{O}$ profiles were taken at 20 stations. 
a)

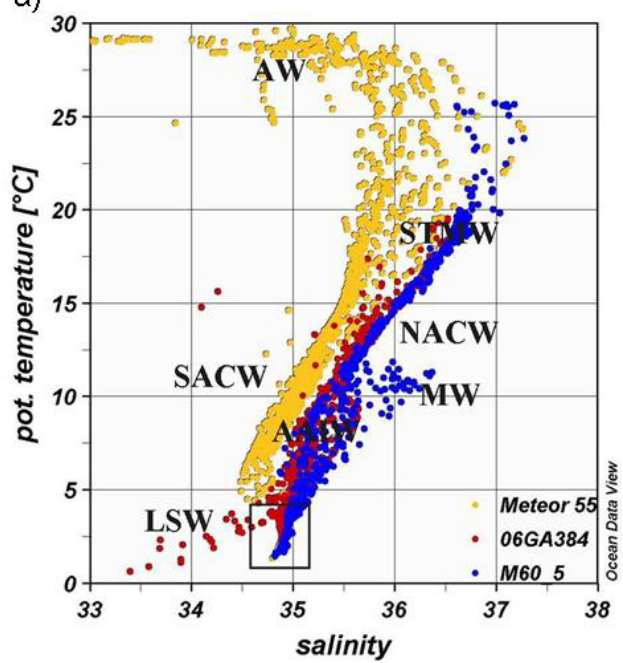

b)

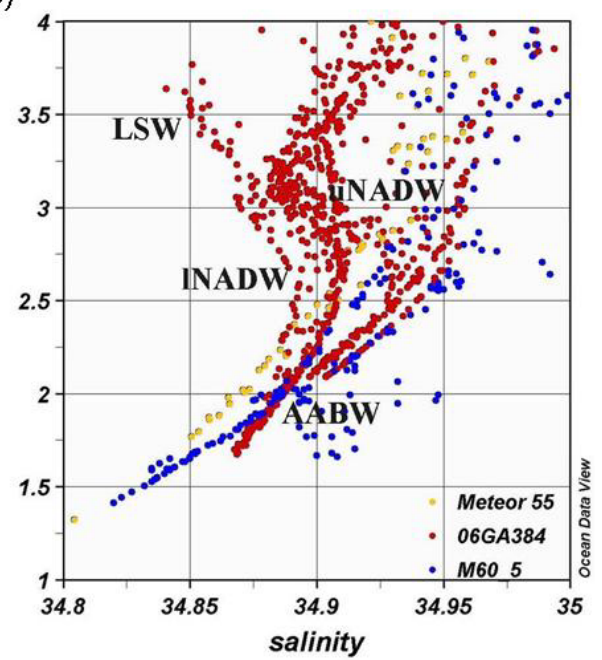

Fig. 2. T-S-diagram of the North Atlantic; (a) T-S-diagram with data from all three cruises; (b) T-S-diagram in Fig. 2a framed by box.; AW: Amazon Water; STMW: Subtropical Mode Water; MW: Mediterranean Water; SACW: South Atlantic Central Water; NACW: North Atlantic Central Water; AAIW: Antarctic Intermediate Water, AABW: Antarctic Bottom Water; 1NADW: lower North Atlantic Deep Water; uNADW: upper North Atlantic Deep Water; LSW: Labrador Sea Water.

\subsection{Hydrography}

Several water masses in the North Atlantic can be identified in the T-S-diagram based on data from the three cruises (see Fig. 2). The main Atlantic water masses were identified according to commonly used classification schemes (Tomczak, 1999; Alvarez et al., 2004; Aiken et al., 2000; Joyce et al., 2001; Poole and Tomczak, 1999).

The WOCE A2 transect (Gauss 384-1 cruise), is located at the boundary region between the subpolar gyre (Gordon, 1986) and the subtropical gyre (Krauss, 1996). This region is highly variable, characterized by the exchange of upper-ocean water between the gyres mainly via the North Atlantic Current, and the Labrador Current. One of the most important water masses here is the Labrador Sea Water (LSW). These water masses provide the major part of the North Atlantic Intermediate Water in combination with the outflow of Mediterranean Sea Water (MW), which is detected in the eastern basin of the subtropical Atlantic Ocean near the Strait of Gibraltar (Richardson et al., 2000) and the Antarctic Intermediate Water (AAIW) from the south (Lorbacher, 2000). Additional water masses of the southern hemisphere that penetrate into the North Atlantic are the South Atlantic Central Water (SACW) and the Antarctic Bottom Water (AABW). SACW flows northwards, and mixes with the North Atlantic Central Water (NACW) at approximately $15^{\circ} \mathrm{N}$ in the western and $20^{\circ} \mathrm{N}$ in the eastern basin (Poole and Tomczak, 1999; Aiken et al., 2000).

A typical freshwater influence was found during the Meteor 55 cruise in the western tropical North Atlantic. Water of the Amazon was detected in the surface water, identified by high temperatures and low salinity. These plumes of freshwater are transported northwards by the North Brazil Current and eastwards by the equatorial current system (Fratantoni and Glickson, 2002).

\section{Material and methods}

Water samples for $\mathrm{N}_{2} \mathrm{O}$ analysis were collected in triplicate from various depths, taken with a 24-Niskin-bottle rosette, equipped with a CTD-sensor. The analytical method applied is a modification of the method described by Bange et al. (2001). Bubble free samples were taken immediately following oxygen sampling in $24 \mathrm{~mL}$ glass vials, sealed directly with butyl rubber stoppers and crimped with aluminium caps. To prevent microbial activity, samples were poisoned with $500 \mu \mathrm{L}$ of $2 \mathrm{mM}$ mercury (II) chloride solution. $10 \mathrm{~mL}$ of sample were then replaced with a helium headspace for each vial, and the samples were then allowed to equilibrate for at least two hours at room temperature (temperature was recorded continuously). A $9 \mathrm{~mL}$ subsample from the headspace was used to flush a $2 \mathrm{~mL}$ sample loop after passing through a moisture trap (filled with Sicapent ${ }^{\circledR}$, Merck Germany). Gaschromatographic separation was performed at $190^{\circ} \mathrm{C}$ on a packed molecular sieve column $\left(6 \mathrm{ft} \times 1 / 8^{\prime \prime} \mathrm{SS}\right.$, $5 \mathrm{~A}$, mesh 80/100, Alltech $\mathrm{GmbH}$, Germany). The $\mathrm{N}_{2} \mathrm{O}$ was detected with an electron capture detector. A mixture of argon with $5 \%$ by volume methane was used as carrier gas with a flow of $21 \mathrm{~mL} \mathrm{~min}{ }^{-1}$. For the two-point calibration procedure we used standard gas mixtures with $311.8 \pm 0.2 \mathrm{ppb}$ and $346.5 \pm 0.2 \mathrm{ppb} \mathrm{N}_{2} \mathrm{O}$ in synthetic air (Deuste Steininger 


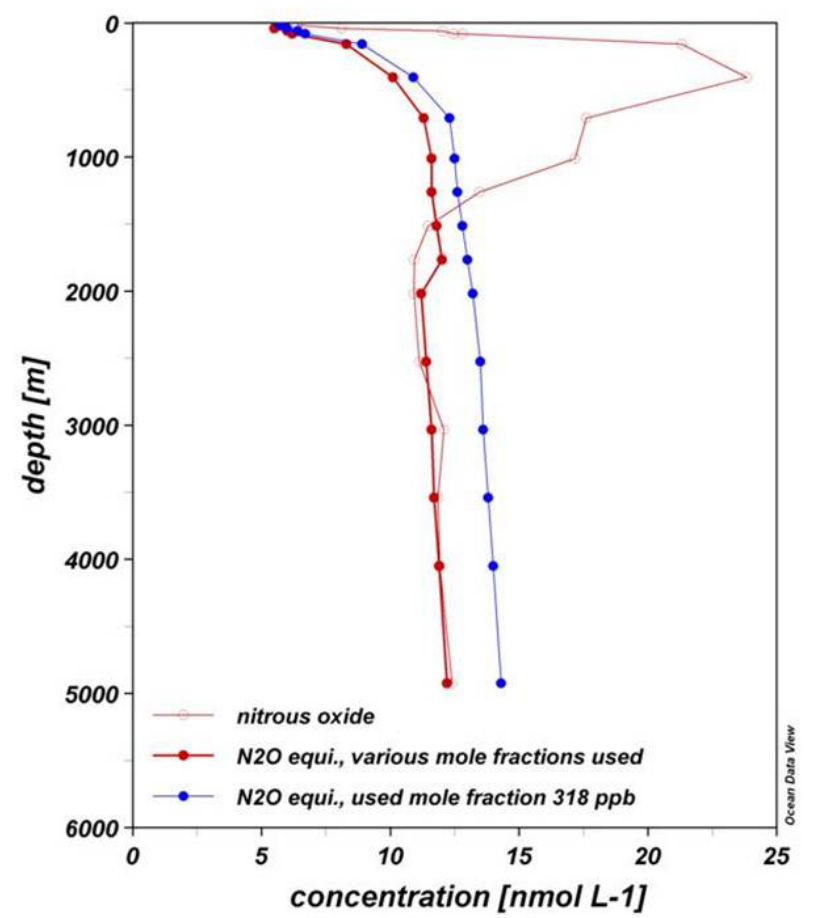

Fig. 3. Measured $\mathrm{N}_{2} \mathrm{O}$ concentration in comparison with the $\mathrm{N}_{2} \mathrm{O}$ equilibrium concentration based on a uniform mole fraction of $318 \mathrm{ppb}$ and the depth-dependent $\mathrm{N}_{2} \mathrm{O}$ equilibrium concentration based on mole fractions of $318 \mathrm{ppb}, 294 \mathrm{ppb}$ and $270 \mathrm{ppb}$. Data are from station 4 of cruise Meteor 55 in the tropical North Atlantic.

GmbH, Mühlhausen Germany). The standard mixtures have been calibrated against the NOAA (National Oceanic and Atmospheric Administration, Boulder, Co.) standard scale in the laboratories of the Air Chemistry Division of the Max Planck Institute for Chemistry, Mainz, Germany.

\subsection{Calculations}

$\mathrm{N}_{2} \mathrm{O}$ water concentrations $\left(\mathrm{C}_{\mathrm{N}_{2} \mathrm{O}}\right)$ were calculated as follows:

$$
\mathrm{C}_{\mathrm{N}_{2} \mathrm{O}}\left[\mathrm{nmolL}^{-1}\right]=\left(\beta x P V_{w p}+\frac{x P}{R T} V_{h s}\right) / V_{w p}
$$

where $\beta$ stands for the Bunsen solubility in $\mathrm{nmol} \mathrm{L}^{-1} \mathrm{~atm}^{-1}$ (Weiss and Price, 1980), $\mathrm{x}$ is the dry gas mole fraction of $\mathrm{N}_{2} \mathrm{O}$ in the headspace in ppb, $\mathrm{P}$ is the atmospheric pressure in atm, $\mathrm{V}_{w p}$ and $\mathrm{V}_{h s}$ stand for the volumes of the water and headspace phases, respectively. $\mathrm{R}$ is the gas constant

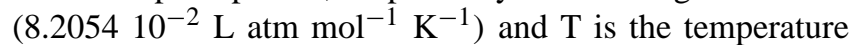
during equilibration. The salinity was measured by the CTDSensor during water sample collection. The overall relative mean analytical error was estimated to be $\pm 1.8 \%$.

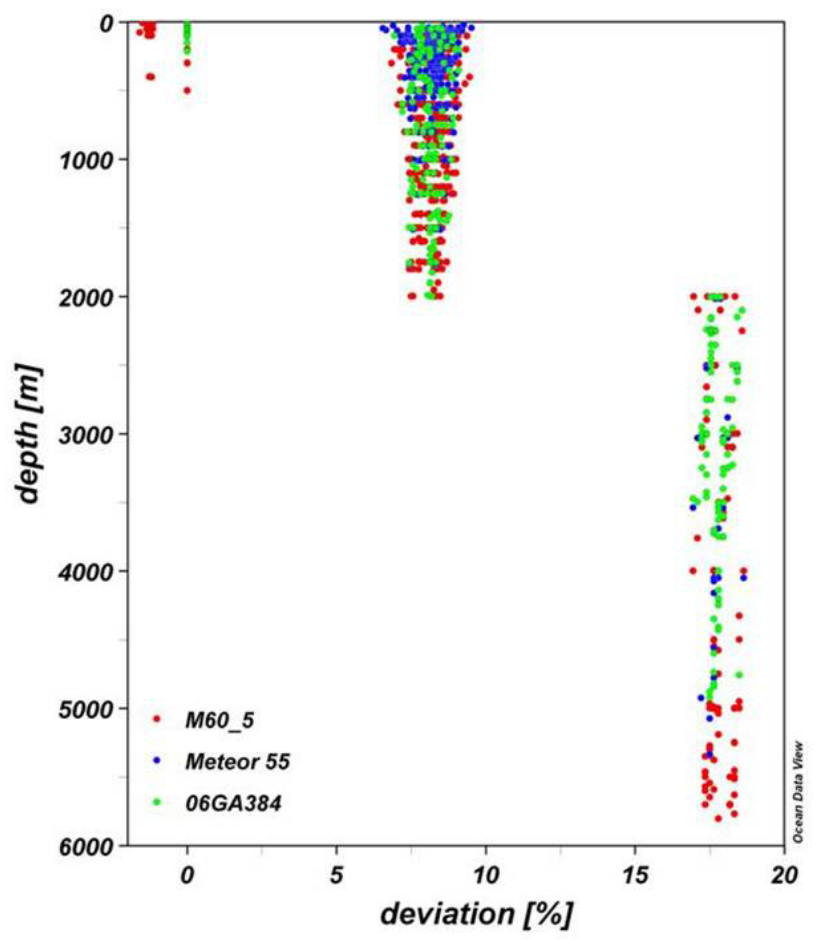

Fig. 4. The percentage deviation between the calculated $\mathrm{N}_{2} \mathrm{O}$ equilibrium concentration based on a uniform mole fraction of $318 \mathrm{ppb}$ and the depth-dependent $\mathrm{N}_{2} \mathrm{O}$ equilibrium concentration based on mole fractions of $318 \mathrm{ppb}, 294 \mathrm{ppb}$ and $270 \mathrm{ppb}$. The three different cruises are colour-coded.

The excess $\mathrm{N}_{2} \mathrm{O}\left(\Delta \mathrm{N}_{2} \mathrm{O}\right)$ was calculated as the difference between the calculated $\mathrm{N}_{2} \mathrm{O}$ equilibrium concentration and the measured concentration of $\mathrm{N}_{2} \mathrm{O}$ as follows

$$
\Delta \mathrm{N}_{2} \mathrm{O}\left(\mathrm{nmolL}^{-1}\right)=\mathrm{N}_{2} \mathrm{O}(\text { observed })-\mathrm{N}_{2} \mathrm{O}(\text { equilibrium }) \text {. }
$$

To calculate the $\mathrm{N}_{2} \mathrm{O}$ equilibrium concentration we used three different atmospheric mole fractions. Between the mixed layer and the atmosphere, $\mathrm{N}_{2} \mathrm{O}$ exchanges in about three weeks (Najjar, 1992), thus we calculated $\Delta \mathrm{N}_{2} \mathrm{O}$ in the mixed layer using the actual atmospheric $\mathrm{N}_{2} \mathrm{O}$ value of $318 \mathrm{ppb}$ measured during the "Meteor 55" cruise (Walter et al., 2004). Below the thermocline, exchange with the atmosphere is unlikely, thus, calculated $\mathrm{N}_{2} \mathrm{O}$ equilibrium concentrations depend on the atmospheric $\mathrm{N}_{2} \mathrm{O}$ mole fraction at the time of deep-water formation. However, the exact atmospheric mole fraction of $\mathrm{N}_{2} \mathrm{O}$ during deep-water formation is unknown because of uncertainty in age determination of water masses. Generally, tropical Atlantic deep waters below $2000 \mathrm{~m}$ seem to be older than 200 years (Broecker and Peng, 2000). Therefore for depths $>2000 \mathrm{~m} \Delta \mathrm{N}_{2} \mathrm{O}$ was calculated with the tropospheric preindustrial value of $270 \mathrm{ppb}$ (Flückiger et al., 1999). An average of the actual and the preindustrial atmospheric value (i.e., $294 \mathrm{ppb}$ ) was used for the depth range between the upper thermocline and $2000 \mathrm{~m}$. The effect of using depth-dependent mole fractions 
a)

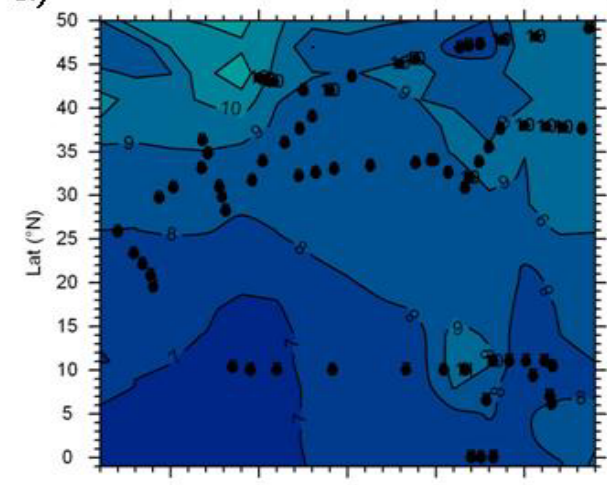

c)

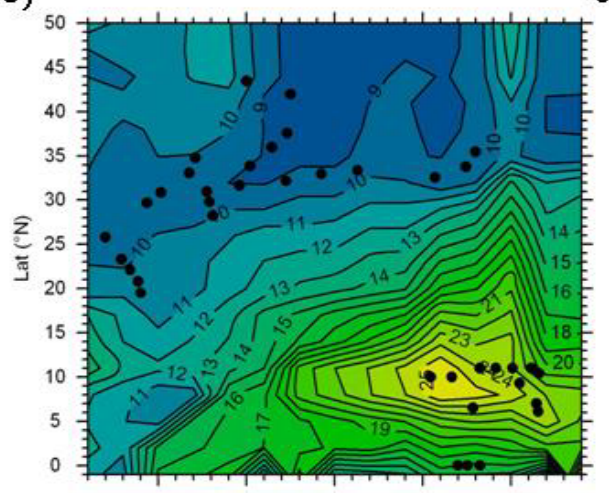

e)

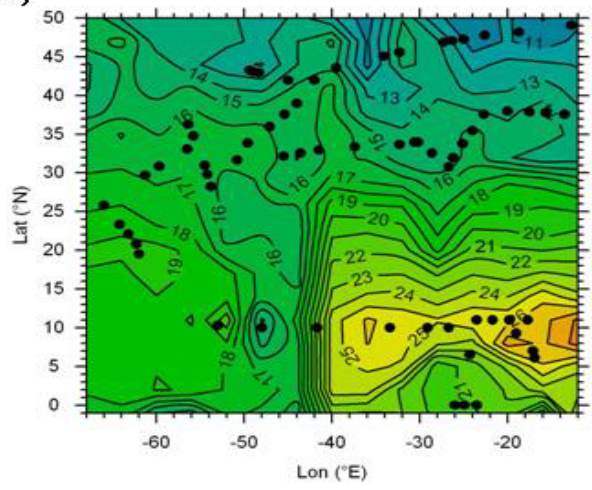

b)

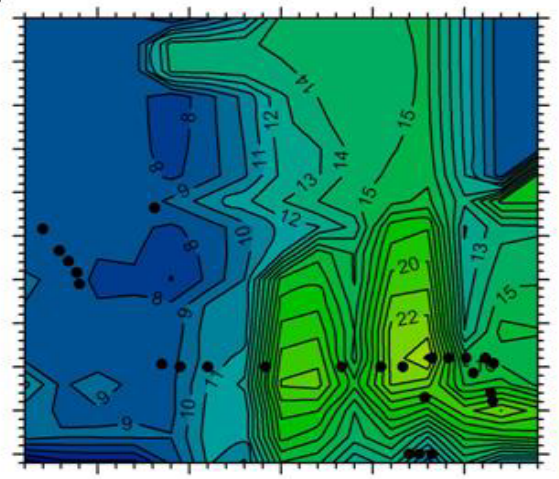

d)

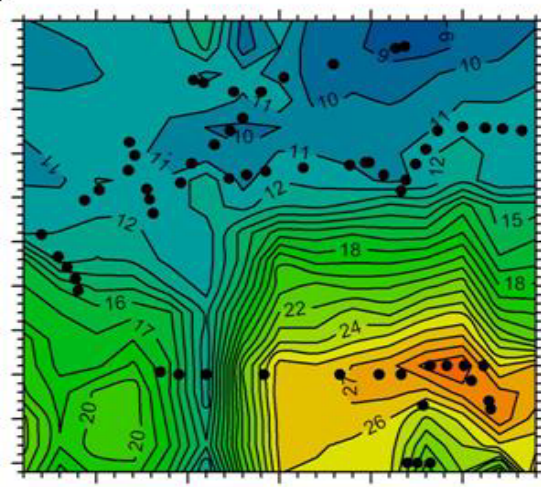

f)

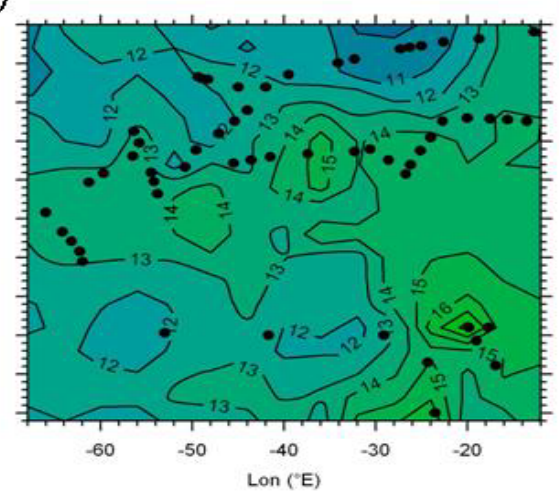

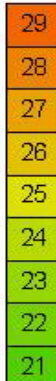

20
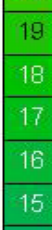

14

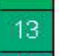

12
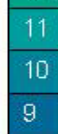

8

0

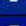

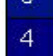

$\mathrm{N}_{2} \mathrm{O}$

$[\mathrm{nmol} / \mathrm{L}]$

Fig. 5. Distribution of $\mathrm{N}_{2} \mathrm{O}$ in the North Atlantic along isopycnal levels $\sigma_{\theta}\left(\mathrm{kg} \mathrm{m}^{-3}\right)$. Dots indicate stations with available data for the isopycnal levels. (a) surface - thermocline; (b) thermocline - 26.0; (c) 26.1 - 26.5; (d) 26.6 - 27.0; (d) 27.1 - 27.5; (f) 27.6 - 27.93.

is shown in Fig. 3 and Fig. 4. With our approach the calculated equilibrium concentration of $\mathrm{N}_{2} \mathrm{O}$ below the thermocline is generally lower than using a uniform $\mathrm{N}_{2} \mathrm{O}$ mole fraction for the whole water column. The difference was $0.789 \pm 0.139 \mathrm{nmol} \mathrm{L}^{-1}(\mathrm{n}=892)$ or about $7 \%$ above $2000 \mathrm{~m}$ and $2.075 \pm 0.044 \mathrm{nmol} \mathrm{L}^{-1}(\mathrm{n}=313)$ or about $17 \%$ below $2000 \mathrm{~m}$.

The thermocline was defined as the depth where the temperature differs from the surface temperature by more than $0.5^{\circ} \mathrm{C}$ (Tomczak and Godfrey, 2001). For the subtropical and cold-temperate region we calculated $\Delta \mathrm{N}_{2} \mathrm{O}$ with these same mole fractions, although the age of water masses is different to the tropical Atlantic and therefore some values may be underestimated, whereas others may be overestimated. The resulting uncertainties of $\Delta \mathrm{N}_{2} \mathrm{O}$ are about 10-15\%; however, our conclusions are not significantly affected by this uncertainty. The equilibrium values of dissolved oxygen $\left(\mathrm{O}_{2}\right)$ were calculated with the equation given by Weiss (1970). The apparent oxygen utilization (AOU) was calculated as follows:

$\mathrm{AOU}\left[\mu \mathrm{mol} \mathrm{L}^{-1}\right]=\mathrm{O}_{2}($ equilibrium $)-\mathrm{O}_{2}$ (observed) 
a)

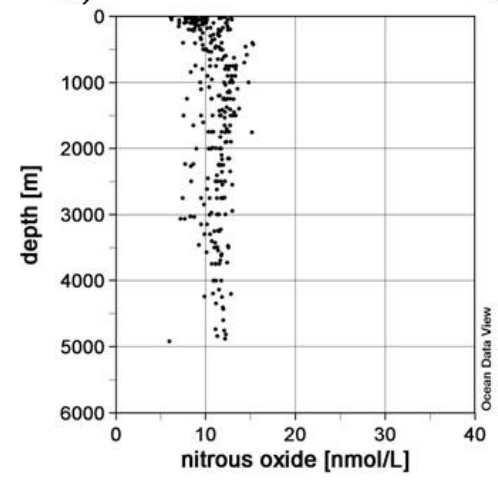

b)

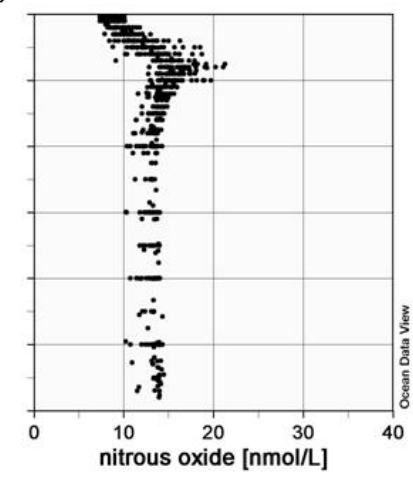

c)

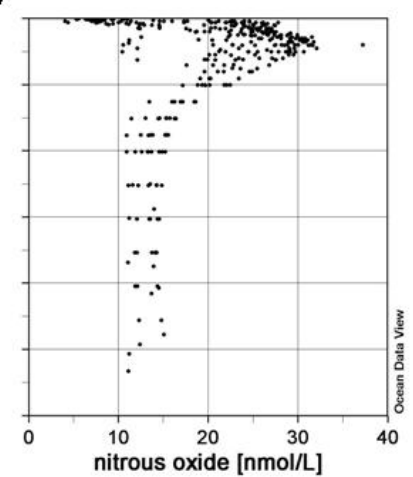

Fig. 6. $\mathrm{N}_{2} \mathrm{O}$ concentration in the North Atlantic plotted against depth. (a) cold-temperate, (b) subtropical, (c) tropical North Atlantic.

\section{Results}

\subsection{Distribution of nitrous oxide in the North Atlantic}

\subsection{1 $\quad \mathrm{N}_{2} \mathrm{O}$ distribution along isopycnal levels}

In the surface layer of the North Atlantic (Fig. 5a) $\mathrm{N}_{2} \mathrm{O}$ concentrations were relatively uniform with $8.5 \pm 1.2 \mathrm{nmol} \mathrm{L}^{-1}$. In the region of the Labrador Current $\mathrm{N}_{2} \mathrm{O}$ concentrations were enhanced with an average of $11.6 \pm 0.9 \mathrm{nmol} \mathrm{L}^{-1}$. During the "Meteor 55" cruise, a plume of Amazon Water had been identified in the western basin of the tropical North Atlantic (Körtzinger, 2003). In contrast to Oudot et al. (2002), who reported enhanced values in the plume of the Amazon River, we found no influence on $\mathrm{N}_{2} \mathrm{O}$ concentrations (Walter et al., 2004).

Below the thermocline, $\mathrm{N}_{2} \mathrm{O}$ concentrations were variable with respect to depths and regions. We found highest concentrations in the eastern basin of the tropical North Atlantic throughout the water column, with maximum concentrations on $\sigma_{\theta}$ surfaces between 26.3 and 27.1 (Fig. 5b-e). At the Midatlantic Ridge, located at approximately $40^{\circ} \mathrm{W}$, a distinct boundary between the western and eastern Atlantic basins was observed (Fig. 5d-e). In the eastern subtropical North Atlantic, at approximately $1000 \mathrm{~m}\left(\sigma_{\theta} 27.6-\right.$ 27.7), a tongue of outflow water from the Mediterranean Sea was detected by higher values of salinity and temperature (Richardson et al., 2000). However, we found no apparent influence of the Mediterranean water on $\mathrm{N}_{2} \mathrm{O}$ concentrations. Like the surface layer, deep waters (Fig. 5f) showed nearly uniform $\mathrm{N}_{2} \mathrm{O}$ concentrations, though with higher values of $13.3 \pm 1.6 \mathrm{nmol} \mathrm{L}^{-1}$. However, a weak but distinct trend of decreasing concentrations from the tropics $\left(13.1 \pm 1.3 \mathrm{nmol} \mathrm{L}^{-1}\right)$ to the cold-temperate North Atlantic $\left(11.1 \pm 1.4 \mathrm{nmol} \mathrm{L}^{-1}\right)$ could be observed.

\subsubsection{Vertical $\mathrm{N}_{2} \mathrm{O}$ distribution}

The vertical distribution of $\mathrm{N}_{2} \mathrm{O}$ showed characteristically different profiles in different regions of the North Atlantic (Fig. 6a-c), and between the western and eastern basins of these regions (Fig. 7a-c).

In the cold-temperate North Atlantic (Fig. 6a) vertical gradients of nitrous oxide were weak over the complete cruise track, with no clear or only a very weakly pronounced subsurface maximum. $\mathrm{N}_{2} \mathrm{O}$ concentrations were near equilibrium $\left(11.0 \pm 1.3 \mathrm{nmol} \mathrm{L}^{-1}\right)$ throughout the water column, with average concentrations of $8.6 \pm 1.4 \mathrm{nmol} \mathrm{L}^{-1}$ in the surface layer $\left(\sigma_{\theta} 25.3-27.0\right)$ and $11.3 \pm 1.5 \mathrm{nmol} \mathrm{L}^{-1}$ below the thermocline down to the bottom $\left(\sigma_{\theta} 26.2-27.7\right)$. No differences between the western and the eastern basin were found (Fig. 7a).

In contrast, $\mathrm{N}_{2} \mathrm{O}$ distributions and profiles in both the subtropical and tropical North Atlantic showed strong variations with water depth (Fig. 6b-c, Fig. 7b-c). In both regions, the profiles generally had one distinct maximum. In the surface layer $\left(\sigma_{\theta} 19.3-26.8\right)$ concentrations were uniform, increasing below the thermocline up to a maximum and decreasing down to approximately $2000 \mathrm{~m}\left(\sigma_{\theta} 22.1-27.8\right)$. Below $2000 \mathrm{~m}\left(\sigma_{\theta} 27.8-27.9\right) \mathrm{N}_{2} \mathrm{O}$ concentrations were nearly constant with depth in both basins.

In the subtropical North Atlantic (Fig. 6b) $\mathrm{N}_{2} \mathrm{O}$ surface concentrations were $8.7 \pm 0.7 \mathrm{nmol} \mathrm{L}^{-1}$, comparable to those in the cold-temperate North Atlantic. Maximum values were found at depths between 600 to $1000 \mathrm{~m}\left(\sigma_{\theta} 26.7-27.7\right)$; values ranged from 14.0 in the eastern basin (\#198) to $21.3 \mathrm{nmol}$ $\mathrm{L}^{-1}$ in the western basin (\#156). Below $2000 \mathrm{~m}\left(\sigma_{\theta}>27.8\right)$, concentrations were nearly constant at $13.1 \pm 0.9 \mathrm{nmol} \mathrm{L}^{-1}$. Profiles in the western subtropical North Atlantic showed distinct maxima, while in the eastern basin no clear maximum was expressed (Fig. 7b). From the western to the eastern basin maximum concentrations decreased slightly from $17.7 \pm 1.4 \mathrm{nmol} \mathrm{L}^{-1}$ to $15.1 \pm 0.7 \mathrm{nmol} \mathrm{L}^{-1}$. East of the 


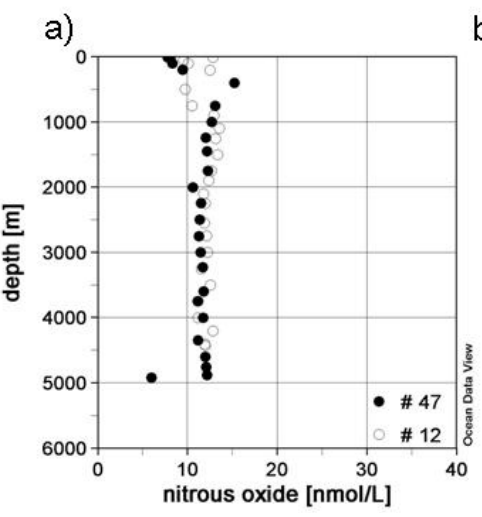

b)

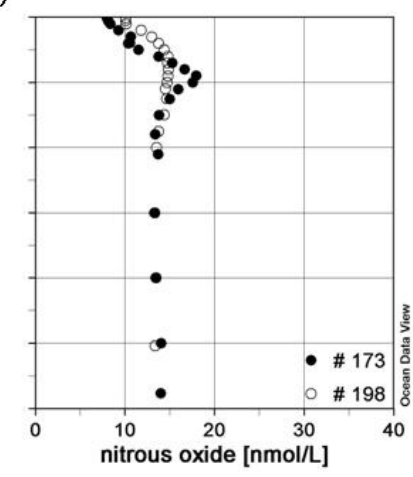

c)

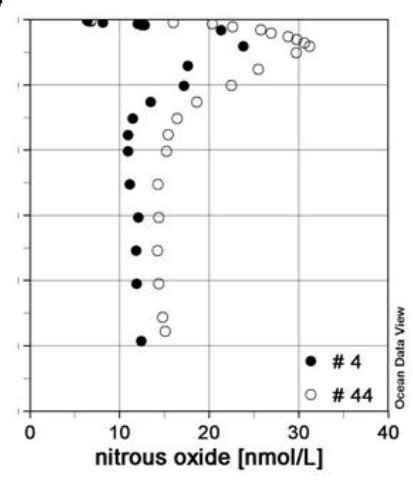

Fig. 7. Selected vertical $\mathrm{N}_{2} \mathrm{O}$ profiles in the western basin (filled symbols) and the eastern basin (open symbols) in the North Atlantic. Stations were indicated by numbers. (a) cold-temperate, (b) subtropical, (c) tropical North Atlantic.

Midatlantic Ridge maxima were not clearly expressed and were broader. Additionally, maximum $\Delta \mathrm{N}_{2} \mathrm{O}$ values were lower in the eastern $\left(5.5 \pm 0.6 \mathrm{nmol} \mathrm{L}^{-1}\right)$ than in the western basin $\left(7.9 \pm 1.3 \mathrm{nmol} \mathrm{L}^{-1}\right)$.

In the tropical North Atlantic (Fig. 6c) surface concentrations, with an average of $7.4 \pm 1.1 \mathrm{nmol} \mathrm{L}^{-1}$, were slightly lower than in the subtropical and cold-temperate North Atlantic. In contrast to the subtropical North Atlantic, maxima of $\mathrm{N}_{2} \mathrm{O}$ concentrations were found at shallower depths of approximately $400 \mathrm{~m}\left(\sigma_{\theta} 26.8-27.1\right)$. The maximum values were higher in general, and ranged from $23.8 \mathrm{nmol} \mathrm{L}^{-1}$ in the western basin (\#4) to $32.1 \mathrm{nmol} \mathrm{L}^{-1}$ in the eastern basin (\#44). At station \#36, located in the Guinea Dome area (Siedler et al., 1992; Snowden and Molinari, 2003), we observed the highest $\mathrm{N}_{2} \mathrm{O}$ values of about $37.3 \mathrm{nmol} \mathrm{L}^{-1}$ at $400 \mathrm{~m}\left(\sigma_{\theta}\right.$ 27.0) (Fig. 6c). At the equatorial stations the $\mathrm{N}_{2} \mathrm{O}$ maxima were found at shallower water depths ( $240 \mathrm{~m}$ to $280 \mathrm{~m}, \sigma_{\theta} 26.6-27.0$ ). Maximum values ranged from $22.3 \mathrm{nmol} \mathrm{L}^{-1}$ (\#26) to $24.9 \mathrm{nmol} \mathrm{L}^{-1}$ (\#24). Below $2000 \mathrm{~m}\left(\sigma_{\theta}>27.8\right)$ concentrations in the tropical North Atlantic were similar to those in the subtropics with an average of $13.2 \pm 1.3 \mathrm{nmol} \mathrm{L}^{-1}$. In both basins of the tropical North Atlantic profiles looked similar with sharp and clear maxima, however, concentrations throughout the water column increased from west to east (Fig. 7c). Below $2000 \mathrm{~m}\left(\sigma_{\theta}>27.8\right)$ $\mathrm{N}_{2} \mathrm{O}$ concentrations were about $2 \mathrm{nmol} \mathrm{L}^{-1}$ higher in the eastern than in the western basin, whereas the difference of the maximum values was even higher (approximately $8 \mathrm{nmol} \mathrm{L}^{-1}$ ).

$\mathrm{N}_{2} \mathrm{O}$ profiles of the subtropical and tropical North Atlantic are in good agreement, both in absolute concentrations and shape of profiles, with those measured during the Bromine Latitudinal Air/Sea Transect II (BLAST II) cruise in Oct./Nov. 1994 (Butler et al., 1995, http://www.cmdl.noaa.gov/hats/ocean/blast2/blastii.html). Comparing our data to those BLAST II data which corre- spond best in position and depths we found a mean $\mathrm{N}_{2} \mathrm{O}$ concentration difference of about $2.05 \pm 1.78 \mathrm{nmol} \mathrm{L-1}$ $(n=92)$. We compared stations $1,2,4,6,7$ and 8 of the BLAST II cruise with station 12 of the Gauss cruise, stations 190, 195, 196, and 197 of the Meteor 60-5 cruise and stations 20, 22, 24, 25, 26 and 27 of the Meteor 55 cruise. In the North Atlantic as far as $20^{\circ} \mathrm{S}$, the mean $\mathrm{N}_{2} \mathrm{O}$ concentration below $1500 \mathrm{~m}$ observed by Butler et al. (1995) was about $13.5 \pm 1.0 \mathrm{nmol} \mathrm{L}^{-1}(\mathrm{n}=18)$ which is in good agreement with our measurements $\left(12.6 \pm 1.5 \mathrm{nmol} \mathrm{L}^{-1}=449\right)$.

\subsection{Comparison of nitrous oxide with other parameters}

Parameters most relevant for comparison with nitrous oxide are those assumed to be directly in connection with production pathways of $\mathrm{N}_{2} \mathrm{O}$, like oxygen or the apparent oxygen utilization (AOU), and nitrate. In general, we found the excess of $\mathrm{N}_{2} \mathrm{O}\left(\Delta \mathrm{N}_{2} \mathrm{O}\right)$ positively correlated with AOU and nitrate (Fig. 8). To account for regional differences we pooled our data set into tropical, subtropical and cold-temperate subsets as shown in Fig. 9. In Fig. 9a-f correlations between $\Delta \mathrm{N}_{2} \mathrm{O}$ with $\mathrm{AOU}$ (Fig. 9a-c) and with $\mathrm{NO}_{3}^{-}$(Fig. 9d-f) are shown for each regional data subset.

Since a multiple regression analysis turned out to be not applicable due to the co-linearity between the independent variables nitrate and AOU, we applied simple regression analysis for the isopycnal levels below the thermocline (see Table 1). Above the thermocline in the surface layer no correlations were found.

In the cold-temperate North Atlantic (Fig. 9a, d) $\Delta \mathrm{N}_{2} \mathrm{O}$ is low, with values near zero. There were no significant correlations found with AOU (Fig. 9a) or nitrate (Fig. 9d; see Tab. 1).

In the subtropical North Atlantic (Fig. 9b, e) $\Delta \mathrm{N}_{2} \mathrm{O}$ was also low with values ranging from 0 to $10 \mathrm{nmoL}^{-1}$. In contrast to the cold-temperate North Atlantic we found significant correlations between $\Delta \mathrm{N}_{2} \mathrm{O}$, AOU (Fig. 9b) and nitrate 

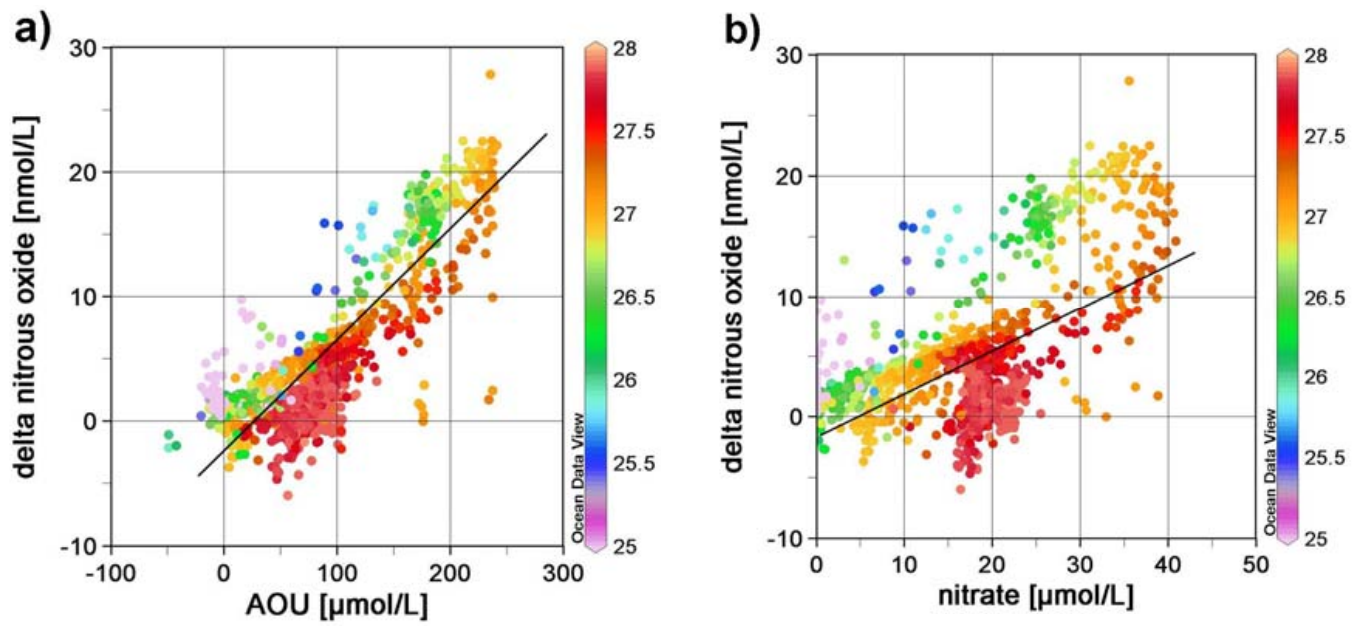

Fig. 8. $\Delta \mathrm{N}_{2} \mathrm{O}$ in comparison with $\mathrm{AOU}$ (a) and nitrate (b) for the North Atlantic, sigma $\sigma_{\theta}$ is colour coded in $\mathrm{kg} \mathrm{m}^{-3}$. $\mathrm{y}\left(\Delta \mathrm{N}_{2} \mathrm{O}\right)=0.089 x(\mathrm{AOU})-3.245, \mathrm{R}^{2}=0.714 ; \mathrm{y}\left(\Delta \mathrm{N}_{2} \mathrm{O}\right)=0.331 \times\left(\mathrm{NO}_{3}^{-}\right)-1.263, \mathrm{R}^{2}=0.322$

(Fig. 9e; see Table 1), especially at depths down to the $\mathrm{N}_{2} \mathrm{O}$ maxima (ca.1000 m; $\sigma_{\theta}<27.7$; see regression lines in Fig. 9b, e). Below $1000 \mathrm{~m}\left(\sigma_{\theta} 27.7\right) \Delta \mathrm{N}_{2} \mathrm{O}$ did not correlate with $\mathrm{AOU}$ or $\mathrm{NO}_{3}^{-}$(circled data in Figs. $9 \mathrm{~b}$ and $7 \mathrm{e}$ ).

In the tropical North Atlantic (Fig. 9c, f) correlations between $\Delta \mathrm{N}_{2} \mathrm{O}$, AOU (Fig. 9c) and nitrate (Fig. 9f) were more pronounced. We observed different $\Delta \mathrm{N}_{2} \mathrm{O} / \mathrm{AOU}$ ratios at depths down to $\Delta \mathrm{N}_{2} \mathrm{O}$ maxima and below the $\Delta \mathrm{N}_{2} \mathrm{O}$ maxima down to the bottom. From the surface layer down to $500 \mathrm{~m}\left(\sigma_{\theta}<27.1\right.$; see regression line a) the slope of the regression line $\left(\Delta \mathrm{N}_{2} \mathrm{O} / \mathrm{AOU}\right)$ was approximately $20 \%$ lower than at depths below $500 \mathrm{~m}\left(\sigma_{\theta}>27.1\right.$; see regression line b). This either implies that the yield of $\mathrm{N}_{2} \mathrm{O}$ for a given $\mathrm{AOU}$ is lower at shallower depths or may reflect mixing effects.

\section{Discussion}

Based on our results, we were able to assign measured $\mathrm{N}_{2} \mathrm{O}$ concentrations to the water masses as shown in Fig. 2a (see Fig. 10). In the following we discuss distributions and possible origins of nitrous oxide at different depths with regard to these water masses.

\section{$5.1 \mathrm{~N}_{2} \mathrm{O}$ in the surface layer of the North Atlantic}

In the surface layer of the North Atlantic the distribution of $\mathrm{N}_{2} \mathrm{O}$ was relatively uniform, with concentrations near equilibrium. This is in line with the assumption that denitrification and nitrification as sources of nitrous oxide in the surface layer seem to be negligible due to the high oxygen concentrations and light inhibition of nitrification (Horrigan et al., 1981). Thus, correlations between $\Delta \mathrm{N}_{2} \mathrm{O}$, AOU and nitrate were nonexistent. Accordingly, we suggest that the $\mathrm{N}_{2} \mathrm{O}$ distribution in the surface layer is most likely driven by solubility and mixing effects. This is also applicable for the enhanced $\mathrm{N}_{2} \mathrm{O}$ concentrations found in the Labrador Current. The $\Delta \mathrm{N}_{2} \mathrm{O}$ concentrations, which are corrected for temperature, showed no enhanced values in this region. Thus, higher $\mathrm{N}_{2} \mathrm{O}$ concentrations in the Labrador Current are likely caused by the solubility effect as well. In the warmer surface layer of the tropical North Atlantic $\Delta \mathrm{N}_{2} \mathrm{O}$ values were up to $4 \mathrm{nmol} \mathrm{L}^{-1}$, indicating the tropical North Atlantic acts as a weak source for atmospheric $\mathrm{N}_{2} \mathrm{O}$ (see also Walter et al., 2004).

\section{2 $\mathrm{N}_{2} \mathrm{O}$ below the surface layer down to $2000 \mathrm{~m}$}

Variations of $\mathrm{N}_{2} \mathrm{O}$ vertical profiles reflected effects of water mass ventilation and sub-surface $\mathrm{N}_{2} \mathrm{O}$ production history. In the cold-temperate North Atlantic we assume that the hydrographic setting (such as convection processes during deep water formation and vertical mixing) is responsible for the observed concentrations and distributions of $\mathrm{N}_{2} \mathrm{O}$ and $\Delta \mathrm{N}_{2} \mathrm{O}$. The most important feature in the cold-temperate North Atlantic is the formation of deep water in winter in the Labrador and Irminger Seas as part of the North Atlantic circulation in 500 to $2000 \mathrm{~m}$ (Rhein, 2000), which carries the atmospheric $\mathrm{N}_{2} \mathrm{O}$ imprint to depth. Labrador Sea Water spreads rapidly east- and southwards (Rhein, 2000) and thus causes the uniform distribution of $\mathrm{N}_{2} \mathrm{O}$ within the coldtemperate North Atlantic. Although the productivity of phytoplankton is relatively high in the cold-temperate North Atlantic, we assume low biological production of $\mathrm{N}_{2} \mathrm{O}$ because of two factors: 1) high oxygen concentrations and 2) low temperatures. The yield of $\mathrm{N}_{2} \mathrm{O}$ depends on oxygen concentration (Goreau et al., 1980; Poth and Focht, 1985; Richardson, 2000; Codispoti et al., 1992), where high oxygen concentrations weaken the production of $\mathrm{N}_{2} \mathrm{O}$. Furthermore the 
a)

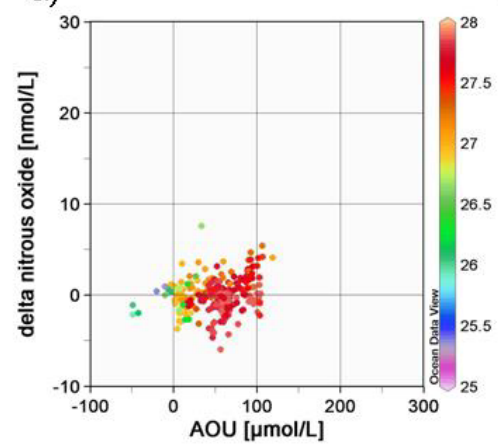

d)

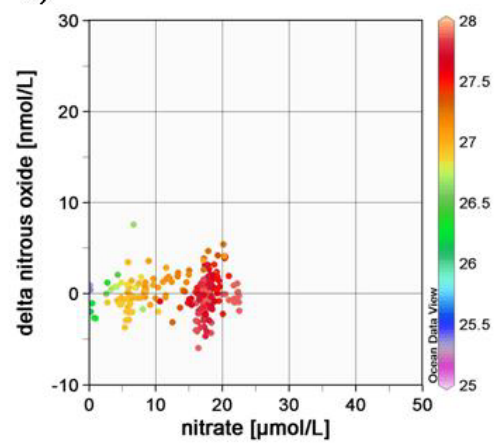

b)

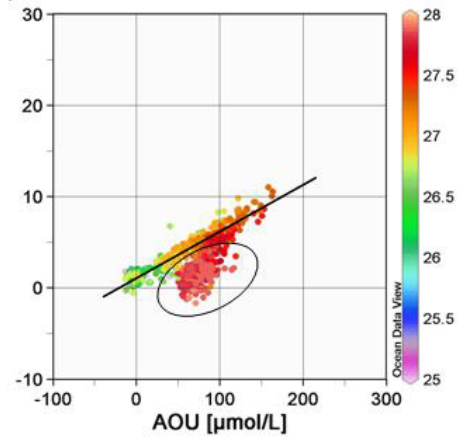

e)

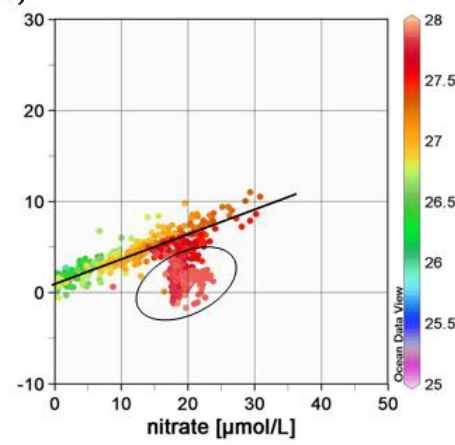

c)

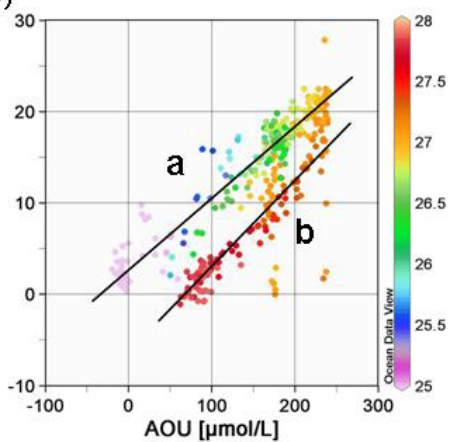

f)

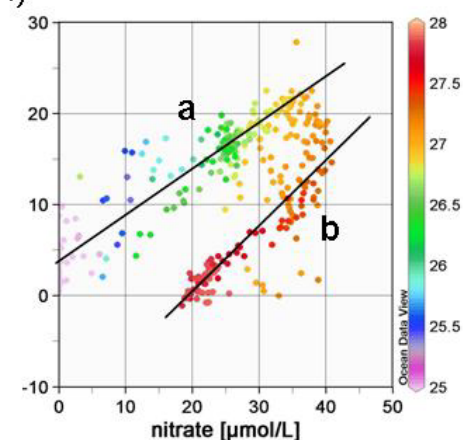

Fig. 9. $\Delta \mathrm{N}_{2} \mathrm{O}$ in comparison with AOU (a-c) and nitrate $(\mathrm{d}-\mathrm{f})$, sigma $\sigma_{\theta}$ is colour coded in $\mathrm{kg} \mathrm{m}^{-3}$.

(a) and (d) cold-temperate North Atlantic;

(b) and (e) subtropical North Atlantic;

$\mathrm{y}\left(\Delta \mathrm{N}_{2} \mathrm{O}\right)=0.0473 \mathrm{x}(\mathrm{AOU})+1.1409, \mathrm{R}^{2}=0.86$ for $\sigma_{\theta}<27.7(\sim<1000 \mathrm{~m})$;

$\mathrm{y}\left(\Delta \mathrm{N}_{2} \mathrm{O}\right)=0.2497 \mathrm{x}\left(\mathrm{NO}_{3}^{-}\right)+1.1776, \mathrm{R}^{2}=0.80$ for $\sigma_{\theta}<27.7(\sim<1000 \mathrm{~m})$;

circled data represent $\sigma_{\theta}>27.7(\sim>1000 \mathrm{~m})$

(c) and (f) tropical North Atlantic;

(c) line a: y $\left(\Delta \mathrm{N}_{2} \mathrm{O}\right)=0.0785 \mathrm{x}(\mathrm{AOU})+2.4381, \mathrm{R}^{2}=0.87$ for $\sigma_{\theta}<27.1(\sim<500 \mathrm{~m})$;

line b: $\mathrm{y}\left(\Delta \mathrm{N}_{2} \mathrm{O}\right)=0.0942 \mathrm{x}$; (AOU) $-6.6675, \mathrm{R}^{2}=0.81$ for $\sigma_{\theta}>27.1(\sim>500 \mathrm{~m})$;

(f) line a: y $\left(\Delta \mathrm{N}_{2} \mathrm{O}\right)=-0.4848 \mathrm{x}\left(\mathrm{NO}_{3}^{-}\right)+3.1756, \mathrm{R}^{2}=0.79$ for $\sigma_{\theta}<27.1(\sim<500 \mathrm{~m})$;

line b: $\mathrm{y}\left(\Delta \mathrm{N}_{2} \mathrm{O}\right)=0.7379 \mathrm{x}\left(\mathrm{NO}_{3}^{-}\right)-14.665, \mathrm{R}^{2}=0.79$ for $\sigma_{\theta}>27.1(\sim>500 \mathrm{~m})$

low temperatures of the North Atlantic might have been crucial as well. The temperature dependence of both nitrification rates and enzyme activities is controversially discussed (Berounsky and Nixon, 1990; Vouve et al., 2000; Barnard et al., 2005; Herbert, 1999; Rheinheimer, 1964; Hansen et al., 1981; Rysgaard et al., 1996), however growth rates and biological production of bacteria clearly depend on the prevailing temperatures (Bock and Wagner, 2001; Hoppe et al., 2002). Thus, $\mathrm{N}_{2} \mathrm{O}$ production might not be limited directly by temperature but indirectly by the limited abundance of $\mathrm{N}_{2} \mathrm{O}$ producing microorganisms.

In the subtropical North Atlantic concentrations of $\mathrm{N}_{2} \mathrm{O}$ and $\Delta \mathrm{N}_{2} \mathrm{O}$ were distinctly higher compared to the coldtemperate North Atlantic. Profiles differed clearly between the western and eastern basin. $\mathrm{N}_{2} \mathrm{O}$ profiles in the western basin showed clearly expressed $\mathrm{N}_{2} \mathrm{O}$ maxima between 600 to $1000 \mathrm{~m}$. This pattern was not observable east of the Mi- datlantic Ridge where $\mathrm{N}_{2} \mathrm{O}$ and $\Delta \mathrm{N}_{2} \mathrm{O}$ concentrations were lower than in the western basin, and no peak maxima were observed. Hydrographic processes likely explain the shape of profiles, especially the advection of Labrador Sea Water (LSW) into the eastern basin. LSW with low $\mathrm{N}_{2} \mathrm{O}$ concentrations is transported either along the eastern continental slope of America or across the Charlie-Gibbs-Fracture-Zone (Bower et al., 2002). It flows into the eastern subtropical basin at 500-2000 m (Rhein, 2000; Alvarez et al., 2004), and spreads north- and southwards (Bower et al., 2002; Rhein, 2000). In the western basin $\mathrm{N}_{2} \mathrm{O}$ concentrations and profiles are in agreement with profiles published by Yoshinari (1976), who also found maximum values in water masses with lower oxygen concentrations. These were identified as Antarctic Intermediate Water (AAIW), which flows northwards. We assume the AAIW transports $\mathrm{N}_{2} \mathrm{O}$ from the south to the cold-temperate North Atlantic. At depths shallower 
Table 1. Regression analyses between $\Delta \mathrm{N}_{2} \mathrm{O}$ and $\mathrm{AOU}$, and $\Delta \mathrm{N}_{2} \mathrm{O}$ and $\mathrm{NO}_{3}^{-}$at different isopycnal levels. Bold numbers mean relationships with significance levels of $\mathrm{p}<0.001$ and $\mathrm{R}^{2}>0.5$. The coefficients a and $\mathrm{b}$ mean slope and intercept.

\begin{tabular}{|c|c|c|c|c|c|c|c|c|}
\hline \multirow[t]{2}{*}{ region } & \multirow[t]{2}{*}{ sigma } & \multirow[b]{2}{*}{$\mathrm{n}$} & \multicolumn{3}{|c|}{$\Delta \mathrm{N}_{2} \mathrm{O} / \mathrm{AOU}$} & \multicolumn{3}{|c|}{$\Delta \mathrm{N}_{2} \mathrm{O} / \mathrm{NO}_{3}^{-}$} \\
\hline & & & $\mathrm{a}$ & $\mathrm{b}$ & $\mathrm{R}^{2}$ & $\mathrm{a}$ & $\mathrm{b}$ & $\mathrm{R}^{2}$ \\
\hline \multirow[t]{5}{*}{ cold-temperate } & thermocline -26.0 & - & - & - & - & - & - & - \\
\hline & $26.1-26.5$ & - & - & - & - & - & - & - \\
\hline & $26.6-27.0$ & 13 & 0.045 & -0.209 & 0.21 & 0.205 & -0.882 & 0.09 \\
\hline & $27.1-27.5$ & 49 & 0.028 & -0.452 & 0.23 & 0.159 & -1.087 & 0.14 \\
\hline & $27.6-27.9$ & 179 & 0.022 & -1.714 & 0.07 & 0.164 & -3.240 & 0.03 \\
\hline \multirow[t]{5}{*}{ subtropical } & thermocline -26.0 & - & - & - & - & - & - & - \\
\hline & $26.1-26.5$ & 45 & 0.038 & 1.307 & 0.58 & 0.297 & 1.337 & 0.51 \\
\hline & $26.6-27.0$ & 106 & 0.065 & 0.397 & 0.75 & 0.390 & 0.186 & 0.68 \\
\hline & $27.1-27.5$ & 121 & 0.055 & 0.426 & 0.67 & 0.312 & -0.052 & 0.60 \\
\hline & $27.6-27.9$ & 355 & 0.069 & -3.083 & 0.38 & -0.126 & 4.579 & 0.02 \\
\hline \multirow[t]{5}{*}{ tropical } & thermocline -26.0 & 34 & 0.080 & 3.783 & 0.72 & 0.599 & 4.681 & 0.61 \\
\hline & $26.1-26.5$ & 39 & 0.099 & -1.421 & 0.83 & 0.777 & -3.212 & 0.81 \\
\hline & $26.6-27.0$ & 98 & 0.107 & -3.112 & 0.49 & 0.376 & 6.068 & 0.20 \\
\hline & $27.1-27.5$ & 63 & 0.114 & -10.638 & 0.43 & 1.289 & -35.050 & 0.42 \\
\hline & $27.6-27.9$ & 69 & 0.075 & -4.853 & 0.67 & 0.619 & -11.830 & 0.66 \\
\hline
\end{tabular}

than $1000 \mathrm{~m}\left(\sigma_{\theta}<27.7\right) \Delta \mathrm{N}_{2} \mathrm{O}$ was significantly correlated with oxygen utilization and nitrate concentrations (Fig. 9b, e; Table 1), indicating nitrification has contributed to measured $\mathrm{N}_{2} \mathrm{O}$ concentrations. In the tropical North Atlantic the $\mathrm{N}_{2} \mathrm{O}$ profiles and the observed trend along the West-East transect are in overall agreement with recently published data from a transect along $7.5^{\circ} \mathrm{N}$ (Oudot et al., 2002) and a previous study in the Guinea Dome area (Oudot et al., 1990). Although the overall pattern is the same, we observed generally lower $\mathrm{N}_{2} \mathrm{O}$ concentrations than Oudot et al. (2002). This might be a result of a calibration disagreement, supported by measured atmospheric $\mathrm{N}_{2} \mathrm{O}$ values of $316 \mathrm{ppb}$ in 1993 . For example, we found a peak $\mathrm{N}_{2} \mathrm{O}$ concentration of up to $37.3 \mathrm{nmol} \mathrm{L}^{-1}$ in South Atlantic Central Water (SACW) of the eastern basin, whereas Oudot et al. (2002) reported values of up to $60 \mathrm{nmol} \mathrm{kg}^{-1}$. Oudot et al. (2002) assumed enhanced biological activity and remineralization of organic matter in upwelling ecosystems to be responsible for these higher values in the east. However, upwelling in this area is a temporary event (Voituriez et al., 1982; Siedler et al., 1992), and during our cruise no upwelling was observed.

Despite the fact that upwelling might have a long-term large-scale effect, we suppose additional reasons for the higher $\mathrm{N}_{2} \mathrm{O}$ concentrations in the eastern basin. The productivity in the eastern basin is fueled not only by coastal upwelling (Signorini et al., 1999) but also by dust deposition off the West African coast (Mills et al., 2004). Moreover, nutrient input by major tropical rivers such as the Senegal, Gambia and Niger (Perry et al., 1996) contribute to enhanced production off the West African coast, indicated by enhanced chlorophyll a concentrations (for the 2002 seasonal cycle of chlorophyll a see monthly data set of Sea-viewing Wide Field-of-view Sensor (SeaWiFS): http://earthobservatory.nasa.gov/Observatory/Datasets/ chlor.seawifs.html).

Enhanced productivity leads to a high export production (Antia et al., 2001). Subsequently lowered $\mathrm{O}_{2}$ concentrations in the eastern intermediate layers due to the decomposition of organic matter support the production of $\mathrm{N}_{2} \mathrm{O}$. Therefore, enhanced $\mathrm{N}_{2} \mathrm{O}$ concentrations in the eastern basin at this time of year (Oct./Nov. 2002) might be a residual signal of past high production episode (Signorini et al., 1999).

Upwelling events, indicated by lower sea surface temperatures, were only found at the equator. Surface $\mathrm{N}_{2} \mathrm{O}$ concentration and sea surface temperature were positively correlated (Walter et al., 2004), and the comparably shallow $\mathrm{N}_{2} \mathrm{O}$ maxima along the equator were caused by upwelling.

Due to the occurrence of linear relationships between $\Delta \mathrm{N}_{2} \mathrm{O}$ and AOU and between $\mathrm{N}_{2} \mathrm{O}$ and nitrate we conclude that nitrification might be the major pathway of $\mathrm{N}_{2} \mathrm{O}$ formation in the tropical Atlantic Ocean (Yoshida et al., 1989). Like $\mathrm{N}_{2} \mathrm{O}, \Delta \mathrm{N}_{2} \mathrm{O}$ showed an increasing trend from West to East indicating that nitrification is more pronounced in the eastern than the western basin of the tropical Atlantic.

\section{$5.3 \mathrm{~N}_{2} \mathrm{O}$ in deep waters $>2000 \mathrm{~m}\left(\sigma_{\theta}>27.8\right)$}

Because the deep ocean contains high nitrate concentrations, nitrification was assumed to be responsible for $\mathrm{N}_{2} \mathrm{O}$ production (Zehr and Ward, 2002; Bange and Andreae, 1999). Due 
a)

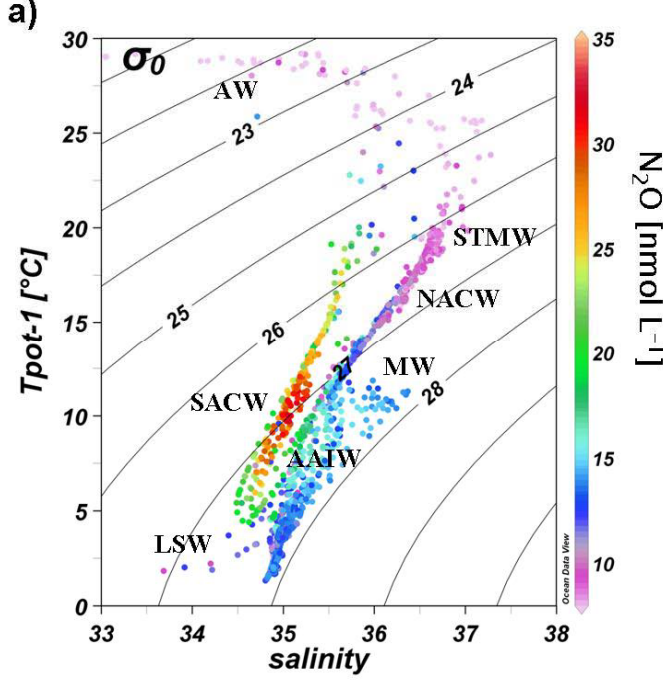

b)

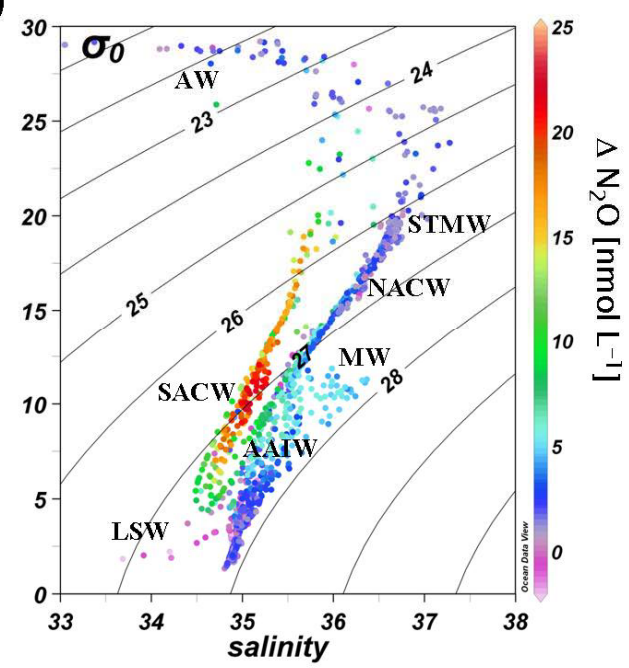

Fig. 10. $\mathrm{N}_{2} \mathrm{O}$ concentration (a) and $\Delta \mathrm{N}_{2} \mathrm{O}$ (b) distributed in a T-S-diagram, the $\mathrm{N}_{2} \mathrm{O}$ and $\Delta \mathrm{N}_{2} \mathrm{O}$ concentrations are colour coded in nmol $\mathrm{L}^{-1}$. AW: Amazon Water; STMW: Subtropical Mode Water; MW: Mediterranean Water; SACW: South Atlantic Central Water; NACW: North Atlantic Central Water; AAIW: Antarctic Intermediate Water; LSW: Labrador Sea Water.

to the low $\Delta \mathrm{N}_{2} \mathrm{O}$ in deep waters and insufficient correlations with nitrate and $\mathrm{AOU}$, we assume $\mathrm{N}_{2} \mathrm{O}$ at these depths probably originates from deep water formation and mixing processes of southern and northern hemisphere water masses. $\mathrm{N}_{2} \mathrm{O}$ profiles from a cruise into the Antarctic circumpolar current $\left(2^{\circ} \mathrm{E} / 49.5^{\circ} \mathrm{S}\right)$ (Walter et al., 2005) and BLAST II data east of Patagonia reveal distinctly higher $\mathrm{N}_{2} \mathrm{O}$ concentrations in the deep waters of the southern hemisphere, with values of approximately $17 \mathrm{nmol} \mathrm{L}^{-1}$. Northwards transport within Antarctic Bottom Water could lead to enhanced $\mathrm{N}_{2} \mathrm{O}$ concentrations in the deep water of the North Atlantic by mixing and diffusion process.

\section{Summary}

$\mathrm{N}_{2} \mathrm{O}$ concentrations in the North Atlantic showed characteristic variations in the vertical and horizontal distributions. In general, distribution of $\mathrm{N}_{2} \mathrm{O}$ can be explained by a combination of biological and hydrographic reasons. The main conclusions of the present study are

- Production of $\mathrm{N}_{2} \mathrm{O}$ by nitrification occurs mainly in the tropical North Atlantic, especially in the eastern basin. Maximum values were found in the Antarctic Intermediate Water (AAIW) in the western basin, and in the South Atlantic Central Water (SACW) in the eastern basin.

- Vertical $\mathrm{N}_{2} \mathrm{O}$ distribution and shape of profiles in the subtropical North Atlantic originate from production by nitrification and advection of AAIW from the south into the western subtropical North Atlantic, respectively advection of LSW from the north in the eastern subtropical North Atlantic.

- In the cold-temperate North Atlantic mainly mixing processes may control the distribution of $\mathrm{N}_{2} \mathrm{O}$, particularly the deep water formation in the Labrador Sea. Production seems to be negligible.

- Tropical and subtropical regions showed supersaturation throughout the water column, thus the tropical and subtropical North Atlantic act as a source of atmospheric $\mathrm{N}_{2} \mathrm{O}$.

- Outflow water of the Amazon or the Mediterranean Sea does not affect the $\mathrm{N}_{2} \mathrm{O}$ concentration.

Acknowledgements. We thank the captains and crews of FS Meteor and FS Gauss for their help during sampling. We especially thank P. Fritsche, H. P. Hansen, F. Malien and J. Schafstall for nutrient and oxygen measurements and CTD handling during the Meteor cruises. Thanks to K. P. Koltermann and his colleagues of the Bundesamt für Seeschifffahrt und Hydrographie in Hamburg for the opportunity to participate on the cruise "Gauss 384-1". Thanks to R. Hoffmann (Max Planck Institute for Chemistry, Mainz, Germany) for calibration of our standard gas mixtures. We also acknowledge the very constructive comments of three anonymous reviewers. This study was financially supported by the Deutsche Forschungsgemeinschaft (DFG) by grants no WA1434/1, WA1434/3, and WA 1434/5.

Edited by: J. Middelburg 


\section{References}

Aiken, J., Rees, N., Hooker, S., Holligan, P., Bale, A., Robins, D., Moore, G., Harris, R., and Pilgrim, D.: The Atlantic Meridional Transect: overview and synthesis of data, Prog. Oceanogr., 45(34), 257-312, 2000.

Alvarez, M., Perez, F. F., Bryden, H., and Rios, A. F.: Physical and biogeochemical transports structure in the North Atlantic subpolar gyre, J. Geophys. Res.-Oceans, 109(C3), 109, C03027, doi:10.1029/2003JC002015, 2004.

Antia, A. N., Koeve, W., Fischer, G., Blanz, T., Schulz-Bull, D., Scholten, J., Neuer, S., Kremling, K., Kuss, J., Peinert, R., Hebbeln, D., Bathmann, U., Conte, M., Fehner, U., and Zeitzschel, B.: Basin-wide particulate carbon flux in the Atlantic Ocean: Regional export patterns and potential for atmospheric $\mathrm{CO}_{2}$ sequestration, Glob. Biogeochem. Cycles, 15(4), 845-862, 2001.

Bange, H. W., and Andreae, M.O.: Nitrous oxide in the deep waters of the world's oceans, Glob. Biogeochem. Cycles, 13(4), 11271135, 1999.

Bange, H. W., Rapsomanikis, S., and Andreae, M. O.: Nitrous oxide cycling in the Arabian Sea, J. Geophys. Res.-Oceans, 106(C1), 1053-1065, 2001.

Barnard, R., Leadley, P. W., and Hungate, B. A.: Global change, nitrification, and denitrification: A review, Glob. Biogeochem. Cycles, 19, doi:10.1029/2004GB002282, 2005.

Berounsky, V. M., and Nixon, S. W.: Temperature and the annual cycle of nitrification in waters of Narragansett Bay, Limnol. Oceanogr., 35(7), 1610-1617, 1990.

Bock, E. and Wagner, M.: Oxidation of inorganic nitrogen compounds as an energy source, in: The Prokaryotes: An Evolving Electronic Resource for the Microbiological Community, $3^{\text {rd }}$ edition, release 3.7, Springer Verlag, New York, 2001.

Bower, A. S., Le Cann, B.,. Rossby, T., Zenk, W., Gould, J., Speer, K., Richardson, P. L., Prater, M. D., and Zhang, H. M.: Directly measured mid-depth circulation in the northeastern North Atlantic Ocean, Nature, 419(6907), 603-607, 2002.

Broecker, W. S. and Peng, T.-H.: Comparison of ${ }^{39} \mathrm{Ar}$ and ${ }^{14} \mathrm{C}$ ages for waters in the deep ocean, Nucl. Instrum. Meth. B, 172, 473478, 2000

Butler, J. H., Lobert, J. M., Yvon, S. A., and Geller, L. S.: The distribution and cycling of halogenated trace gases, in: Reports on Polar Research No. 168 - The expedition ANTARKTIS XII of RV "Polarstern" in 1994/95: Reports of legs ANT XII/1 and 2, edited by: Kattner, G. and Fütterer, D. K., pp. 33-40, Alfred Wegener Institute for Polar and Marine Research, Bremerhaven, 1995.

Codispoti, L. A., Brandes, J. A., Christensen, J. P., Devol, A. H., Naqvi, S. W. A., Paerl, H. W., and Yoshinari, T.: The oceanic fixed nitrogen and nitrous oxide budgets: Moving targets as we enter the anthropocene?, Sci. Mar., 65(Suppl. 2), 85-105, 2001.

Codispoti, L. A., Elkins, J. W., Yoshinari, T., Friederich, G. E., Sakamoto, C. M., and Packard, T. T.: On the nitrous oxide flux from productive regions that contain low oxygen waters, 271284 pp., Oxford and IBH, New Delhi (India), 1992.

Cohen, Y. and Gordon, L. I.: Nitrous oxide in the oxygen minimum of the eastern tropical North Pacific: evidence for its consumption during denitrification and possible mechanisms for its production, Deep-Sea Res., 25(6), 509-524, 1978.

Flückiger, J., Dallenbach, A., Blunier, T., Stauffer, B., Stocker, T.
F., Raynaud, D., and Barnola, J. M.: Variations in atmospheric $\mathrm{N}_{2} \mathrm{O}$ concentration during abrupt climatic changes, Science, 285, 5425, 227-230, 1999.

Fratantoni, D. M. and Glickson, D. A.: North Brazil current ring generation and evolution observed with SeaWiFS, J. Phys. Oceanogr., 32, 3, 1058-1074, 2002.

Gordon, A. L.: Interocean exchange of thermohaline water, J. Geophys. Res., 91, 5037-5047, 1986.

Goreau, T. J., Kaplan, W. A., Wofsy, S. C., McElroy, M. B., Valois, F. W., and Watson, S. W.: Production of $\mathrm{NO}_{2}^{-}$and $\mathrm{N}_{2} \mathrm{O}$ by nitrifying bacteria at reduced concentrations of oxygen, Appl. Environ. Microbiol., 40, 3, 526-532, 1980.

Hansen, J. I., Blackburn, T. H., and Henriksen, K.: Seasonal distribution of nitrifying bacteria and rates of nitrification in coastal marine sediments, Microb. Ecol., 7, 4, 297-304, 1981.

Herbert, R. A.: Nitrogen cycling in coastal marine ecosystems, FEMS Microbiol. Rev., 23, 563-590, 1999.

Hoppe, H. G., Gocke, K., Koppe, R., and Begler, C.: Bacterial growth and primary production along a north-south transect of the Atlantic Ocean, Nature, 416(6877), 168-171, 2002.

Horrigan, S. G., Carlucci, A. F., and Williams, P. M.: Light inhibition of nitrification in sea-surface films, J. Mar. Res., 39, 3, 557-565, 1981.

Joyce, T. M., Hernandez-Guerra, A., and Smethie, W. M.: Zonal circulation in the NW Atlantic and Caribbean from a meridional World Ocean Circulation Experiment hydrographic section at $66^{\circ} \mathrm{W}, \mathrm{J}$. Geophys. Res.-Oceans, 106(C10), 22 095-22 113, 2001.

Junge, C. and Hahn, J.: $\mathrm{N}_{2} \mathrm{O}$ measurements in the North Atlantic, J. Geophys. Res., 76(33), 8143-8146, 1971.

Körtzinger, A.: A significant $\mathrm{CO}_{2}$ sink in the tropical Atlantic Ocean associated with the Amazon River plume, Geophys. Res. Lett., 30, 24, 2287, doi: 10.1029/2003GL018841, 2003.

Krauss, W.: Comments on the development of our knowledge of the general circulation of the North Atlantic Ocean, The Warmwatersphere of the North Atlantic Ocean, edited by: Krauss, W., 1-31, Gebrüder Borntraeger, Berlin-Stuttgart, 1996.

Lorbacher, K.: Niederfrequente Variabilität meridionaler Transporte in der Divergenzzone des nordatlantischen Subtropen- und Subpolarwirbels - Der WOCE-Schnitt A2, Bericht des Bundesamtes für Seeschifffahrt und Hydrographie, 22, 156, 2000.

Mills, M. M., Ridame, C., Davey, M., La Roche, J., and Geider, R. J.: Iron and phosphorus co-limit nitrogen fixation in the eastern North Atlantic, Nature, 429, 292-294, 2004.

Najjar, R. G.: Marine biogeochemistry, in: Climate System Modeling, edited by: Trenberth, K. E., pp. 241-280, Cambridge University Press, Cambridge, 1992.

Oudot, C., Andrie, C., and Montel, Y.: Nitrous oxide production in the tropical Atlantic Ocean, Deep-Sea Res. I, 37(2), 183-202, 1990.

Oudot, C., Jean-Baptiste, P., Fourre, E., Mormiche, C., Guevel, M., Ternon, J.-F., and Le Corre, P.: Transatlantic equatorial distribution of nitrous oxide and methane, Deep-Sea Res.I, 49, 11751193, 2002.

Perry, G. D., Duffy, P. B., and Miller, N. L.: An extended data set of river discharges for validation of general circulation models, J. Geophys. Res., 101(D16), 21 339-21 349, 1996.

Poole, R. and Tomczak, M.: Optimum multiparameter analysis of the water mass structure in the Atlantic Ocean thermocline, 
Deep-Sea Res.I-Oceanographic Research Papers, 46(11), 18951921, 1999.

Popp, B. N., Westley, M. B., Toyoda, S., Miwa, T., Dore, J. E., Yoshida, N., Rust, T. M., Sansone, F. J., Russ, M. E., Ostrom, N. E., and Ostrom, P. H.: Nitrogen and oxygen isotopomeric constraints on the origins and sea-to-air flux of $\mathrm{N}_{2} \mathrm{O}$ in the oligotrophic subtropical North Pacific gyre, Glob. Biogeochem. Cycles, 16(4), doi: 10.1029/2001GB001806, 2002.

Poth, M. and Focht, D. D.: ${ }^{15} \mathrm{~N}$ kinetic analysis of $\mathrm{N}_{2} \mathrm{O}$ production by Nitrosomonas europaea - an examination of nitrifier denitrification, Appl. Environ. Microbiol., 49(5), 1134-1141, 1985.

Prather, M., Ehhalt, D., Dentener, F., Derwent, R., Dlugokencky, E., Holland, E., Isaksen, I., Katima, J., Kirchhoff, V., Matson, P., Midgley, P., and Wang, M.: Atmospheric chemistry and greenhouse gases, in: Climate Change 2001: The Scientific Basis. Contribution of Working Group I to the Third Assessment Report of the Intergovernmental Panel on Climate Change, edited by: Houghton, J. T., Ding, Y., Griggs, D. J., Noguer, M., Van der Linden, P. J., Dai, X., Maskell, K., and Johnson, C. A., 239-287, Cambridge University Press, Cambridge, UK, 2001.

Rhein, M.: Oceanography - Drifters reveal deep circulation, Nature, 407(6800), 30-31, 2000.

Rheinheimer, G.: Untersuchungen über den Einfluß der Temperatur auf die Nitrifikation im Elbe-Aestuar, Arch. Mikrobiol., 49, 283290, 1964

Richardson, D. J.: Bacterial respiration: a flexible process for a changing environment, Microbiol., 146, 551-571, 2000.

Richardson, P. L., Bower, A. S., and Zenk, W.: A census of Meddies tracked by floats, Prog. Oceanogr., 45(2), 209-250, 2000.

Robertson, L. A., van Niel, E. W. J., Torremans, R. A. M., and Kuenen, J. G.: Simultaneous nitrification and denitrification in aerobic chemostat cultures of Thiosphaera pantotropha, Appl. Environ. Microbiol., 54(11), 2812-2818, 1988.

Rysgaard, S., Finster, K., and Dahlgaard, H.: Primary production, nutrient dynamics and mineralisation in a northeastern Greenland fjord during the summer thaw, Polar Biol., 16(7), 497-506, 1996.

Seitzinger, S. P., Kroeze, C., and Styles, R. V.: Global distribution of $\mathrm{N}_{2} \mathrm{O}$ emissions from aquatic systems: Natural emissions and anthropogenic effects, Chemosphere: Global Change Sci., 2(3), 267-279, 2000.

Siedler, G., Zangenberg, N., and Onken, R.: Seasonal changes in the tropical Atlantic circulation - Observation and simulation of the Guinea Dome, J. Geophys. Res.-Oceans, 97(C1), 703-715, 1992.

Signorini, S. R., Murtugudde, R. G., McClain, C. R., Christian, J. R., Picaut, J., and Busalacchi, A. J.: Biological and physical signatures in the tropical and subtropical Atlantic, J. Geophys. Res.Oceans, 104(C8), 18367-18 382, 1999.
Snowden, D. P. and Molinari, R. L.: Subtropical cells in the Atlantic Ocean: An observational summary, in: Interhemispheric Water Exchange in the Atlantic Ocean, edited by: Goni, G. J., and Malanotte-Rizzoli, P., pp. 287-312, Elsevier, New York, 2003.

Tomczak, M.: Some historical, theoretical and applied aspects of qualitative water mass analysis, J. Mar. Res., 57, 275-303, 1999.

Tomczak, M. and Godfrey, J. S.: Regional Oceanography: An Introduction, 391, 2001.

Voituriez, B., Herbland, A., and Leborgne, R.: Equatorial upwelling in the eastern Atlantic during FGGE, Oceanol. Acta, 5(3), 301314, 1982.

Vouve, F., Guiraud, G., Marol, C., Girard, M., Richard, P., and Laima, M. J. C.: $\mathrm{NH}_{4}^{+}$turnover in intertidal sediments of Marennes-Oleron Bay (France): effect of sediment temperature, Oceanol. Acta, 23(5), 575-584, 2000.

Wallace, D. W. R. and Bange, H. W.: Introduction to special section: Results of the Meteor 55: Tropical SOLAS Expedition, Geophys. Res. Lett., 31(L23S01), 1-4, 2004.

Walter, S., Bange, H. W., and Wallace, D. W. R.: Nitrous oxide in the surface layer of the tropical North Atlantic Ocean along a west to east transect, Geophys. Res. Lett., 31(23), L23S07, doi:10.1029/2004GL019937, 2004.

Walter, S., Peeken, I., Lochte, K., and Bange, H. W.: Nitrous oxide measurements during EIFEX, the European Iron Fertilisation Experiment in the subpolar South Atlantic Ocean, Geophys. Res. Lett., 32, L23613,doi: 10.1029/2005GL024619, 2005.

Weiss, R. F.: The solubility of nitrogen, oxygen and argon in water and seawater, Deep-Sea Res., 17, 721-735, 1970.

Weiss, R. F. and Price, B. A.: Nitrous oxide solubility in water and seawater, Mar. Chem., 8, 347-359, 1980.

Yoshida, N., Morimoto, H., Hirano, M., Koike, I., Matsuo, S. Wada, E., Saino, T., and Hattori, A.: Nitrification rates and ${ }^{15} \mathrm{~N}$ abundances of $\mathrm{N}_{2} \mathrm{O}$ and $\mathrm{NO}_{3}^{-}$in the western North Pacific, Nature, 342, 895-897, 1989.

Yoshinari, T.: Nitrous oxide in the sea, Mar. Chem., 4, 189-202, 1976.

Yoshinari, T., Altabet, M. A., Naqvi, S. W. A., Codispoti, L., Jayakumar, A., Kuhland, M., and Devol, A.: Nitrogen and oxygen isotopic composition of $\mathrm{N}_{2} \mathrm{O}$ from suboxic waters of the eastern tropical North Pacific and the Arabian Sea - Measurement by continuous-flow isotope-ratio monitoring, Mar. Chem., 56(3-4), 253-264, 1997.

Zehr, J. P. and Ward, B. B.: Nitrogen cycling in the ocean: New perspectives on processes and paradigms, Appl. Environ. Microbiol., 68(3), 1015-1024, 2002. 